\title{
Students' Perceptions of Academic Writing: A Needs Analysis of EAP in China
}

\author{
Luna Jing Cai \\ The University of Hong Kong, Hong Kong, China
}

\begin{abstract}
Academic writing remains a prominent issue for students and teachers in Asian EFL contexts. English courses offered in mainland China at tertiary levels mostly focus on teaching English for general purposes, and few concern writing for academic purposes, even for English majors. This small-scale needs analysis study reports on a survey of 50 Master of Arts students in English who are part of a new English for Academic Purposes program at a university in south China, as well as a focus group interview with a smaller group. Results indicate that $70 \%$ of the participants have never taken an academic writing course before and that the academic writing skills students found difficult are those less frequently taught. Students want a new course which provides them with generic features for writing the sections in a research article / thesis and, more importantly, the linguistic resources needed for writing academic papers appropriately.
\end{abstract}

\section{Current Teaching of Academic English at the University Level in China}

Tertiary students in EFL contexts are often faced with a gap between their limited command of L2 English academic literacies and their much more developed L1 academic literacies. In mainland China, while many universities are becoming more globally oriented, few institutions have established English language centers to provide specific linguistic consultancy for nonnative English-speaking students, as those in English-dominant countries or other contexts in Asia (e.g., Hong Kong and Singapore) have done. The majority of universities in mainland China offer "College English" courses, employing a textbook oriented for College English Test (CET) preparation that emphasizes grammar drilling (Zhang \& Luo, 2004) and overlooks academic writing. Due to local constraints such as "large class size, disjunction between classroom instruction and the CET test and students' test-driven learning styles" (You, 2004, p. 255), students' academic writing proficiency remains low.

As a result, Chinese students are constantly reported as able to attain high scores on grammarbased tests yet unable to write acceptable English compositions. According to Xu (2005), most Chinese students would like to rely on writing handbooks or directly imitate the format of published articles by borrowing certain expressions when required to write academic papers. Even though academic / thesis writing courses are offered in a few universities, they are usually teacher-centered lectures, with only referencing skills and thesis layout being taught, while elaborations on moves [the smallest discourse units that perform a certain communicative or

Language Education in Asia, 2013, 4(1), 5-22. http://dx.doi.org/10.5746/LEiA/13/V4/I1/A2/Cai 
rhetorical function (Swales, 1990)] or steps and linguistic features used in academic papers are ignored.

Non-English majors, except for the minority who want to apply for study abroad, do not seem to have much practical need to learn academic writing, as most colleges in mainland China do not require these students to write undergraduate or graduate theses in English, and some require theses to be written in Chinese only (personal communication with students in various disciplines). While some departments have taken the initiative to change textbooks for core courses to imported ones from the United States, answering the call for bilingual education in colleges (Department of Higher Education, 2001), most of these courses are still taught solely in Chinese due to the limited English proficiency of instructors. Students are thus free to choose which language to use in writing their assignments (Liang, 2006).

\section{Needs for Academic Writing Instruction for English Majors in Mainland China}

For most English majors in Chinese universities, especially the top ones, all assignments for courses and theses are required to be in English. However, although this group of students has been consistently required to write essays or research papers in English, the academic writing proficiency of English majors remains low (Sun, 2004). An important reason may be that few academic writing courses are offered. Sun (2004) surveyed 147 English-major Master of Arts (MA) students from 52 colleges and universities and found that only around $16 \%$ of the institutions offered academic writing courses for English majors and 15\% of students had never been taught academic writing as undergraduates. Among these students, almost half reported having problems writing their Bachelor of Arts (BA) theses in proper academic writing styles. Major difficulties students experienced included their inability to express ideas in academic English, the lack of guidance on searching for proper references, and even uncertainty about the thesis or research paper format.

Taking into account the special context where postgraduate English majors in mainland China receive their ELT education, with academic writing being the most urgent need for the completion of their studies, they were chosen as the group to study. It is hoped that the results of this study can serve as a window for investigating the transformation of the College English unit, which is becoming a needs-based institute helping postgraduate students become international scholars across disciplines.

\section{Needs Analysis}

Needs Analysis (NA), i.e., identifying students' needs, is the essential initial step in developing an appropriate specialized English syllabus, as asserted by many researchers (e.g., DudleyEvans \& St. John, 1998; Hyland, 2006; Kavaliauskiene \& Uzpaliene, 2003; West, 1994). It is the technique used to evaluate the how and what of a course. NA has been regarded as the most appropriate method as it "can tell us a lot about the nature and content of the learners' target language needs" (Hutchinson, 1988, p. 71). Generally speaking, in NA, the course designer has to gather information about students' present and target situations (Dudley-Evans \& St. John, 1998), through present situation analysis (PSA) and target situation analysis (TSA). Hutchinson and Waters (1987) developed TSA and PSA into a more manageable framework, adopted in the present research. They identified three components of target needs: necessity (needs identified by the requirements of target situation), lacks (the necessary proficiency for the target situation compared to what the students already know), and wants (what the students desire to learn). 
There have been a few large-scale empirical NA studies carried out in Asian or Chinese ELT contexts. Major investigations conducted at tertiary institutions in Hong Kong include Hyland (1997), Littlewood and Liu (1996), and Evans and Green (2007). All these studies indicated that productive skills and acquisition of specialist vocabulary were the central language concerns of participants. Evans and Green pinpointed the striking problem of vocabulary and suggested that English for Academic Purposes (EAP) program design should attach great importance to the teaching and learning of "subject-specific and common core lexis" (p. 14).

However, due to the nature of comprehensive and large-scale surveys, none of these studies was specific to academic writing, and the specific nature of language problems as the most important hindrance was not identified in detail. The surveys provided a general picture of Hong Kong tertiary students' proficiency in all four English macro skills, while little was mentioned about the form and quality of academic writing courses offered. The present study thus aims to look into academic writing in particular. It attempts to explore students' attitudes towards learning academic writing, their current level in some academic writing skills, their biggest concerns in learning academic writing, and their opinions on previous and future academic writing courses. The findings are expected to help EAP practitioners develop an appropriate English academic writing course for English majors in south China and offer insights into the EAP agenda in the broader Asian EFL context.

This research was guided by the following three questions:

1. What are MA students' perceptions of the importance of academic writing to their current studies and future career? (What are the purposes and motivations that drive them to learn?)

2. What are the students' perceptions of the difficulties of academic writing skills?

3. What are the students' attitudes towards their previous academic writing courses? (What do they want to learn in future EAP courses? And how?)

\section{Participant Background}

\section{Method}

Participants were selected from first-year MA students at a key university in south China. Fifty students were available at the time of the study and were willing to participate. They had obtained their bachelor's degrees from various universities, and their diverse backgrounds offered rich information about their previous academic writing courses. This group of students was selected based on two criteria: a) they were the same cohort who would participate in a new EAP program and b) they represented the group of students who have the most urgent need in learning academic writing for their current studies and future careers.

There has been no academic writing course offered for postgraduate students in this university. The leaders of the Foreign Language School believe that students are able to acquire academic writing skills by themselves (personal communication with department head), and that what they need are the "research methods" and "basic structures" that can guide their design and the contents of research paper writing / thesis writing. It is assumed that academic language does not have to be taught explicitly. Thus even undergraduate students with little experience in academic writing who need to write BA theses in English are only provided with several hours of lectures about the basic structure and the format of a thesis.

\section{Questionnaire Design}

The questionnaire items were developed according to Hutchinson and Waters' (1987) framework of NA. Fifteen items were divided into three major sections (see Appendix). Section I (necessity) focused on investigating students' motivation (orientations / purposes) for learning 
academic writing and the importance of different academic genres. Another item was added regarding students' intrinsic interest in learning academic writing, beyond "academic / personal goals" (Hutchinson \& Waters, 1987, p. 62), as intrinsic interest has been considered an important element in many second-language motivation studies (e.g., Dörnyei, 2005). Section II (lacks) explored students' perceptions on the difficulty of 18 important academic writing skills (adapted from Evans \& Green, 2007). Section III (wants) first enquired about students' attitudes towards previous academic writing courses, if any, taken as undergraduates. Students who had not taken academic writing courses only indicated their preference for prospective teaching activities and materials. Further questions were asked on the aspects of knowledge (language problems or general writing skills) they would like to be emphasized and the five most important academic writing skills that should be included in the new academic writing course. The survey took around 30 minutes to complete.

\section{Focus Group Interview}

A follow-up focus group interview was conducted after the survey analysis to gain in-depth information which might not be shown in the survey. The interview was conducted mostly in Chinese because the participants were more comfortable expressing themselves in their native language. Each participant was given a sheet with the interview prompts in both languages. As the participants were English majors with sufficient proficiency to understand the prompts, no questions were asked to clarify anything on the sheet during the interview. The interview was fully transcribed and translated into English by the researcher.

Six students were selected based on their willingness to participate (two students had taken an academic writing course before). This number of students was considered optimal, as students could have a face-to-face roundtable discussion and build on each other's responses to think of ideas they might not have in individual interviews. The interview took around one hour and questions similar to those in the survey were asked, but in a clearer and simpler way, for example: "What do you want to improve most in your academic writing?" and "How did you learn to write a research paper?" Interviewees were also invited to give their comments on certain responses (that might or might not be theirs) and general results from the survey analysis. The interview was recorded and coded for content analysis.

\section{Results and Discussion}

\section{Research Question 1: The Importance of Learning Academic Writing}

In Section I, students were asked to indicate on a 5 -point scale ( 1 being the lowest value and 5 the highest) how important they considered academic writing to be to their current studies, future career, and publishing, and how much intrinsic interest they had in academic writing.

Results generally indicate that while students' imposed needs for learning academic writing are huge, they have little intrinsic interest in learning academic writing. The score of learning academic writing for the purpose of completing current graduate studies is the highest, with a mean of $4.55(S D=0.50)$, as students reported the need to write "for the courses, and for graduation" (focus group comment). While the need for learning academic writing for publication during graduate study is slightly lower $(M=3.98, S D=0.80)$, it is slightly higher than the need for publication during one's future career $(M=3.78, S D=0.97)$. Students find little inner pleasure in academic writing, presenting an average score of only $1.80(1=$ not interested at all).

In the focus group interview, students reported reasons for the relative lack of need for learning academic writing for a future career. First, the journals in the field of education or English 
language in mainland China are mostly published in Chinese. Except for students who will pursue a Ph.D., future need is much less than that for their current studies. The requirement for publishing a research-based paper is relatively lower if they opt to be secondary school teachers rather than college teachers. Finally, most students actually dislike using academic language, as it is "too formal and structured, and has little space for free writing" (focus group comment).

Among the eight text types which participants prioritized by preference, research papers / reports are of the highest concern $(75 \%)$, followed by case studies $(67.5 \%)$. The reason, indicated from the focus group interview, seems to be that research papers are the most widely assessed text type for their graduate studies. Additionally, students perceive that a research paper is like a mini thesis and is closely related to academic publishing. As for case studies, they are the text type the students "know the least about" but prefer to write, since they find that "doing experimental or empirical research is much harder because it is very difficult to control the variables" (focus group comment). Review articles, critiques, and theses are of similar importance; all were checked by about $60 \%$ of the students. The students explained that learning to review and critique is a basic skill for doing research; it is fundamental for developing research topics and identifying research gaps, a skill that might transfer to helping them write thesis literature reviews, one of their largest concerns.

The results agree with the findings of studies on non-native English-speaking undergraduates by Evans and Green (2007) and Al-Tamimi and Shuib (2010) that academic English is very important for the students' academic study. In addition, Evans and Green's (2007) study noted that in particular, "projects and reports play the most important roles in participants' academic lives" (p. 10). However, only a minority of students in Evans and Green's study attached importance to the text type of review, which seemed to suggest that students in Hong Kong tend to see it as less important than the participants in this study did. The authors' explanation was that students were not aware of the close connection of this academic genre with their dissertations. Another explanation, however, might be that as mainland Chinese students suffer from a strong lack of both research paper input (reading) and instruction in academic writing, they are more concerned about the full gamut of academic genres they are unfamiliar with, but which sound important.

\section{Research Question 2: Students' Perceptions of Difficulties of Academic Writing Skills}

Section II listed 18 important academic writing skills for which students indicated their perceived difficulty on a scale from 1 (very easy) to 5 (very difficult). The skills were divided into two parts: general academic writing skills and language problems.

The findings suggested that students experienced greater difficulty $(M=3.42$ out of 5$)$ in writing the structure and content than language-related problems $(M=3.38)$.

As seen in Table 1, the three most difficult general academic writing skills for these students are reviewing and critiquing the previous research and creating a research space (gap), designing research methods, and commentaries and discussions on the data. In contrast, writing references and the introduction posed little difficulty. (The focus group explained that in some undergraduate academic writing courses students had taken, the teachers only taught how to cite references).

With regard to language problems, students were generally confident about their grammar but found it difficult to achieve appropriateness in an academic context, e.g., by using appropriate lexical phrases to build sentences and paragraphs and by understanding the specific language 
features of the genre (such as the research paper). However, it should be noted that the students' perceptions varied conspicuously in terms of language problems, as indicated by the divergent $S D$ scores in the items about grammar and lexical phrases $(S D=1.03$ and $S D=0.98$, respectively).

Table 1

Means of Perceived Difficulty of Academic Writing Skills

\begin{tabular}{|c|c|c|c|}
\hline \multicolumn{2}{|r|}{ Items } & \multirow{2}{*}{$\begin{array}{c}\begin{array}{c}\text { Means } \\
\text { (difficulty) }\end{array} \\
2.83\end{array}$} & \multirow{2}{*}{$\begin{array}{c}S D \\
0.96\end{array}$} \\
\hline \multirow{11}{*}{$\begin{array}{l}\text { General } \\
\text { academic } \\
\text { writing skills } \\
(M=3.42)\end{array}$} & Writing introductions & & \\
\hline & $\begin{array}{l}\text { Searching for appropriate literature using databases } \\
\text { and library resources }\end{array}$ & 3.53 & 0.85 \\
\hline & Referring to sources & 3.28 & 0.82 \\
\hline & $\begin{array}{l}\text { Reviewing and critiquing the previous research and } \\
\text { creating a research space (gap) }\end{array}$ & 4.30 & 0.88 \\
\hline & Designing the research methods & 4.08 & 0.69 \\
\hline & Writing the methods section & 3.74 & 0.88 \\
\hline & Summarizing and presenting the data & 3.53 & 0.91 \\
\hline & Commentaries and discussions on the data & 3.85 & 0.74 \\
\hline & Writing references / bibliography & 2.38 & 0.90 \\
\hline & Writing conclusions & 3.10 & 0.79 \\
\hline & Proofreading written assignments & 3.08 & 0.96 \\
\hline \multirow{7}{*}{$\begin{array}{l}\text { Language } \\
\text { problems } \\
(M=3.38)\end{array}$} & $\begin{array}{l}\text { Understanding the specific language features of the } \\
\text { academic genre (such as research paper) }\end{array}$ & 3.48 & 0.85 \\
\hline & $\begin{array}{l}\text { Using appropriate lexical phrases (such as on the basis } \\
\text { of, it should be noted that) freely to build sentences } \\
\text { and paragraphs }\end{array}$ & 3.80 & 0.98 \\
\hline & Summarizing / paraphrasing & 3.28 & 0.82 \\
\hline & Writing coherent paragraphs & 3.41 & 0.88 \\
\hline & Linking sentences smoothly & 3.25 & 0.84 \\
\hline & $\begin{array}{l}\text { Using proper "academic" language and vocabulary } \\
\text { (style) }\end{array}$ & 3.70 & 0.91 \\
\hline & $\begin{array}{l}\text { Using the proper grammar such as correct tenses, } \\
\text { agreements, reporting verbs, and prepositions }\end{array}$ & 2.79 & 1.03 \\
\hline \multicolumn{2}{|c|}{ Overall Mean Score } & 3.40 & 0.47 \\
\hline
\end{tabular}

Compared with what was documented in the literature review, the results here seem to suggest that students in both Hong Kong and mainland contexts find language problems difficult. Evans and Green (2007) highlighted Hong Kong students' lack of confidence in the language-related aspects of academic writing, especially lexical and grammatical aspects. Students' perceived difficulties in lexical and stylistic aspects of academic writing were also reported in research from other EAP settings where non-native English speakers were required to write (e.g., Hinkel, 
2003; Shaw \& Liu, 1998). However, unlike the students in the current study, undergraduate students in Hong Kong found language problems posed more difficulty than content and structure. The reason for this could be traced back to the different goals in high school English education in Hong Kong and mainland China: while Hong Kong students are exposed to various academic genres and have a basic understanding about structure and content of academic genres before they enter university, mainland Chinese students are generally much less proficient in academic writing, as requirements for English writing for college entrance exams are low, with only general English essays covered. Most mainland Chinese students, up to the postgraduate level, have little knowledge about academic writing, especially the research genres.

\section{Research Question 3: Previous and Future Academic Writing Courses}

What they learned. Section III enquired about students' perceptions of previous and future academic course design and curricula. Results show that $70 \%$ had never taken an academic writing course. This lack of experience is reflected in the remarks of a focus group participant:

We were really surprised when we found out that as research postgraduate students in this university, we were not expected to be taught on how to write academic genres such as research paper and thesis in appropriate language besides the format and structure. We could only learn from imitating the model research papers in the journals which we have limited access to. We don't have much confidence in writing as a result.

Among the 12 students who had taken academic writing courses as undergraduates, eight found the courses "just so-so," one was "not satisfied at all," while four were "generally satisfied." Additionally, in the focus group interview, two students mentioned that "we have almost forgotten what we have learned in the previous academic course." Their teachers did not tell them how to write the sections of academic papers in detail, i.e., the moves and steps in each specific part of a piece of academic writing. Language features such as lexical phrases, academic vocabulary, and coherence were even less frequently addressed. The courses or lectures on academic writing only provided students with "a vague and general picture on what a thesis should be composed of" (focus group comment).

This point is supported by the findings displayed in Table 2. The average frequency for the academic writing skills included in previous academic writing courses is only 2.69 ( $5=$ most frequent). For general academic writing skills, designing and writing research methods were least frequently included in previous academic writing courses (proofreading skills were also ranked low). Language problems were introduced less frequently $(M=2.56)$ than general academic writing skills $(M=2.78)$, with lexical phrases, academic vocabulary, and style the least frequently taught $(M=2.07$ for each).

Furthermore, a significant negative Pearson correlation coefficient $(r(50)=-0.51, p=.032)$ was found between the students' perception of difficulty of academic writing skills and the frequency of these aspects in writing courses; this suggests that the less these skills are taught, the more difficult the students feel they are. 


\section{Table 2}

The Frequency of Academic Writing Skills Taught in Previous Academic Writing Courses

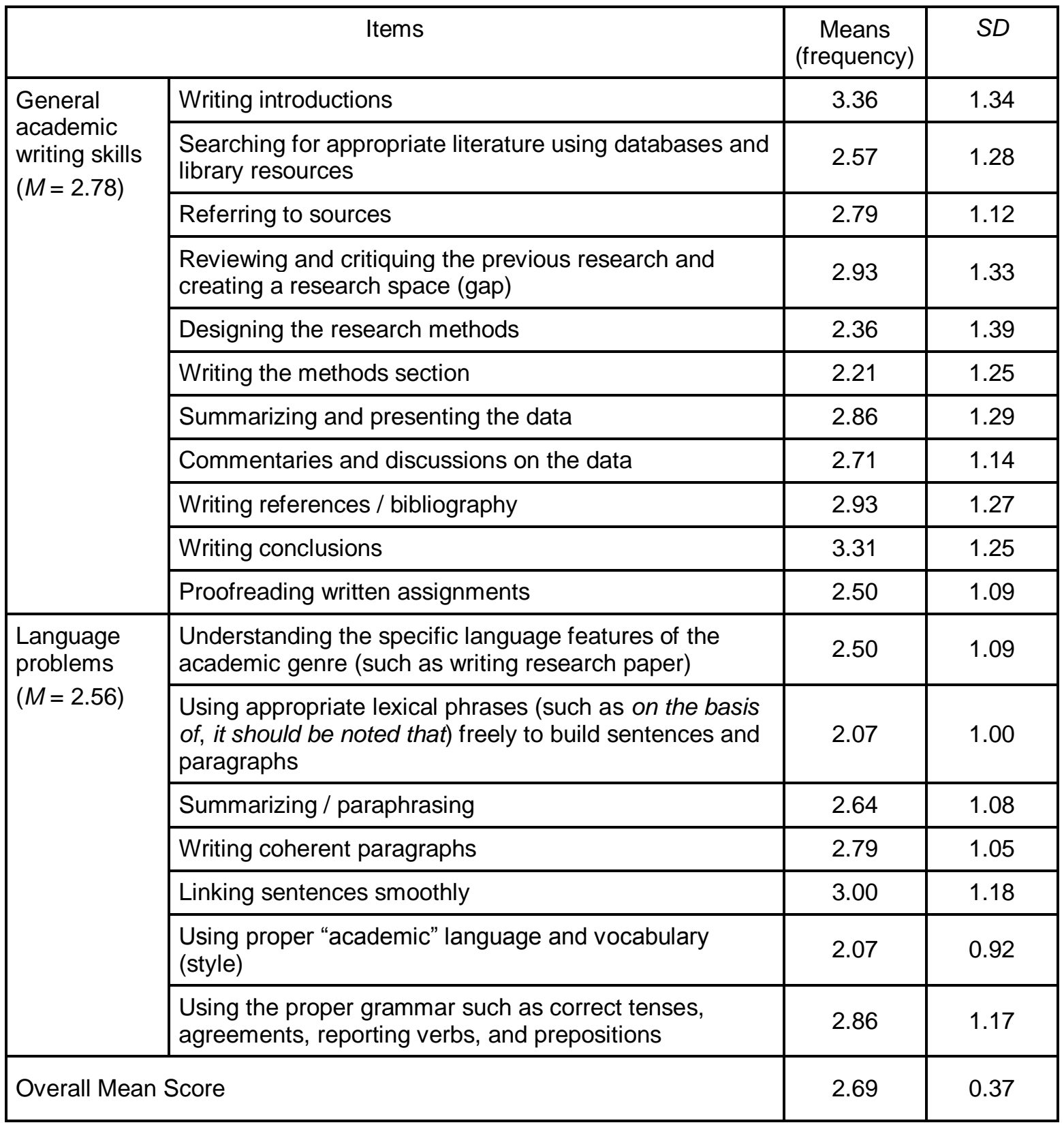

The frequency of other teaching activities in previous academic writing courses also confirmed that language-related activities were rare. Academic grammar and vocabulary drills were the least employed $(\mathcal{M}$ (freq) $=1.88$ and 2.06 , respectively). Reading authentic papers was usually not included as a task in the courses $(M($ freq $)=2.20)$. Generally, teacher-centered lecture was the most frequent teaching method $(M($ freq $)=4.19)$.

What they want to learn. All survey participants indicated the necessity of taking academic writing courses during their graduate studies. For the focus of the proposed new academic writing course, $58 \%$ of them chose "general academic writing skills," and $42 \%$ chose "language problems." Students further emphasized in the focus group interview that even though what they need most at present are general writing skills, they were, according to one 
member, "very unconfident about their use of [academic] language." They noted that it would be more efficient if academic language features were explicitly taught in class rather than learned from model papers.

Students were asked to brainstorm and write the five most important skills they wanted to learn in the new course. The results are presented in Table 3. Four general categories emerged from the answers: thinking, organization, searching for information, and language and vocabulary. Among the 31 respondents, $77 \%$ mentioned learning how to write the different sections (e.g., introduction, literature review, discussion). Commenting on and summarizing findings was also identified in particular (58\%); this may be because students are "not sure what should be presented and how to organize data after analyzing them." They were never taught such skills, and are thus unsure how "to explore on their own after collecting data" (focus group comments).

Table 3

The Most Important Skills Students Want to Learn in the New Course

\begin{tabular}{|l|l|c|}
\hline \multicolumn{2}{|l|}{ Category } & $\%$ \\
\hline \multirow{4}{*}{ Thinking } & Critical thinking & $32 \%$ \\
\cline { 2 - 3 } & Creating research gap & $32 \%$ \\
\cline { 2 - 3 } & Designing research method & $45 \%$ \\
\hline \multirow{4}{*}{ Writing and organization } & Writing different sections of RA (move / steps) & $77 \%$ \\
\cline { 2 - 3 } & Referring to sources & $13 \%$ \\
\cline { 2 - 3 } & Commenting and summarizing findings & $58 \%$ \\
\hline \multirow{3}{*}{ Searching for information } & Finding academic resources, using E-databases & $32 \%$ \\
\hline \multirow{3}{*}{ Language } & Academic language (Style and academic vocabulary) & $30 \%$ \\
\cline { 2 - 3 } & Coherence and cohesion & $16 \%$ \\
\cline { 2 - 3 } & Chunks and phrases & $31 \%$ \\
\hline
\end{tabular}

Preferred teaching activities and materials. Table 4 shows the students' preferences towards possible teaching activities and materials that had been applied in the previous course or that could be used in the new course. Students regarded reading exercises, especially reading authentic research papers, as the most preferable $(M=4.32)$, as well as other kinds of activities, such as group discussion $(M=3.81)$ and academic writing exercises $(M=3.75)$. For teaching materials, students prefer supplementary authentic research papers as models and supplementary handouts slightly more than other materials. 
Research

Table 4

Students' Preference Towards Possible Teaching Activities and Materials in the New Course

\begin{tabular}{|l|l|c|c|}
\hline \multicolumn{2}{|c|}{ Items } & $\begin{array}{c}\text { Means } \\
\text { (preference) }\end{array}$ & SD \\
\hline \multirow{4}{*}{$\begin{array}{l}\text { Teaching } \\
\text { activities }\end{array}$} & Teacher centered lectures & 3.83 & 1.15 \\
\cline { 2 - 4 } & Student oral presentations & 3.55 & 1.21 \\
\cline { 2 - 4 } & Group discussions on tasks & 3.81 & 1.28 \\
\cline { 2 - 5 } & Academic grammar drills & 3.41 & 1.32 \\
\cline { 2 - 5 } & Academic vocabulary drills & 3.38 & 1.34 \\
\cline { 2 - 5 } & Academic writing exercises & 3.75 & 1.08 \\
\cline { 2 - 5 } & Academic reading exercises (reading text books) & 4.00 & 0.88 \\
\cline { 2 - 5 } & Reading and analyzing authentic research papers & 2.32 & 1.01 \\
\hline \multirow{5}{*}{$\begin{array}{l}\text { Teaching } \\
\text { materials }\end{array}$} & The key text book used in class & 3.53 & 1.11 \\
\cline { 2 - 5 } & Other supplementary hand-outs & 3.84 & 1.08 \\
\cline { 2 - 5 } & Supplementary authentic research papers as models & 3.47 & 1.05 \\
\cline { 2 - 5 } & Supplementary exercises & & 1.16 \\
\hline
\end{tabular}

\section{Comparisons to Other Studies}

Unlike this study, little information has been found in other empirical studies concerning what students felt about their previous courses and what they want to be taught in new courses. Difficult skills in academic writing have been identified in broad terms such as "writing correct sentences" (Al-Tamimi \& Shuib, 2010, p. 23) and "communicating ideas properly accurately and smoothly" (Evans \& Green, 2007, p. 11), while specific wants, such as those presented in the current study as potentially beneficial for EAP course designers, have not been addressed.

Besides identifying the suitable curriculum content of an EAP course and its pedagogy, the sociocultural context in mainland China must be taken into account. Unlike their counterparts in Hong Kong (see Evans \& Green, 2007; Hyland, 1997), where there is a long history of ESLmedium education at secondary and tertiary levels, mainland Chinese students have much less exposure to academic genres and language in secondary and tertiary education. This may have resulted in the difference between the findings of this study and the ones obtained in a Hong Kong context, i.e., that mainland Chinese students have problems with basic knowledge about structure and content and more serious linguistic needs. These needs could possibly be fulfilled by EAP genre-based pedagogy (e.g., Swales \& Feak, 2004), which addresses the specific move / steps and language features in the research genres and is mostly task-based with rich classroom discussion. This approach also puts strong emphasis on the in-class guided analysis of authentic genre exemplars where students can develop a strategy for independent learning of different genres in academic writing in the future.

\section{Conclusion}

From detailed survey and focus group interview data, mainland Chinese students' needs in learning academic writing have been suggested. Besides identifying target needs and difficulties students have in academic writing skills in general, as previous studies carried out in Asian contexts have done, this study specifically looks at students' perceptions and attitudes towards their previous academic writing courses and prospective new courses. The skills 
students find difficult are those less taught in their previous academic writing courses. Reviewing and critiquing are perceived as the most difficult general academic writing skills, while using proper academic phrases and style are the most difficult language-related problems. In their previous courses, students were not taught how to write each section of a research paper with appropriate moves / steps and were infrequently introduced to academic language features and styles. As a result, in a proposed new course, they would like to receive more help on these aspects. As for how the knowledge should be delivered, they prefer more reading of authentic research papers with group discussions in class.

Considering these results, an EAP genre-based pedagogy could be a possible and promising solution for EFL learners in mainland China or other Asian countries with similar problems in academic writing. To effect such change, teachers and instructors in university English departments in these contexts may need to consider transforming their thinking about academic writing instruction into an EAP- and ESP (English for Special Purposes)-oriented mode. For example, as a first step, they need to gradually replace outdated textbooks and develop new teaching materials that are compatible with the students' linguistic needs.

Finally, there are several limitations to this study. First, the sample size was relatively small as this study was targeted at developing a contextualized approach for teaching academic writing at the target university. Secondly, whether the results of this study can be generalized to university students in China with other majors who have similar needs remains a question to be further investigated. To inform EAP in China, especially across disciplines, the university's College English unit should conduct a more specific and larger-scale needs analysis across disciplines, including both undergraduate and postgraduate students.

\section{Author Note}

Luna Jing Cai, Faculty of Education, The University of Hong Kong, Hong Kong, China.

This study is part of the Ph.D. project I carried out in mainland China on ESP genre-based academic writing pedagogy. I would like to extend my heartfelt thanks to Dr. Angel Lin, my supervisor, for guiding me through the whole process of research. I am also grateful to the Faculty of Education and The University of Hong Kong for funding this study.

Correspondence concerning this article should be addressed to Jing CAI, Room 201, Hui Oi Chow Science Building, The University of Hong Kong, Pokfulam Road, Hong Kong. E-mail: h1088584@hku.hk 


\section{References}

Al-Tamimi, A., \& Shuib, M. (2010). Investigating the English language needs of the petroleum engineering students at Hardhamount University of Science and Technology. The Asian ESP Journal, 4(1), 6-34.

Department of Higher Education. (2001). Guanyu jiaqiang gaodeng xuexiao benke jiaoxue gongzuo tigao jiaoxue zhiliang de ruogan yijian [On strengthening undergraduate education in improving the quality of teaching in higher institutions]. Beijing, China.

Dörnyei, Z. (2005). The psychology of the language learner: Individual differences in second language acquisition. Mahwah, NJ: Lawrence Erlbaum. http://dx.doi.org/10.1017/S0272263105370288

Dudley-Evans, T., \& St. John, M. (1998). Developments in ESP: A multi-disciplinary approach. Cambridge, England: Cambridge University Press. http://dx.doi.org/10.1016/j.jeap.2006.11.005

Evans, S., \& Green, C. (2007). Why EAP is necessary: A survey of Hong Kong tertiary students. Journal of English for Academic Purposes, 6(1), 3-17. http://dx.doi.org/10.1016/j.jeap.2006.11.005

Hinkel, E. (2003). Simplicity without elegance: Features of sentences in L1 and L2 academic texts. TESOL Quarterly, 372), 275-301. http://dx.doi.org/10.2307/3588505

Hutchinson, T. (1988). Making materials work in the ESP classroom. In D. Chamberlain \& R. J. Baumgardner (Eds.), ESP in the classroom: Practice and evaluation (pp. 71-75). Oxford, England: Modern English Publication in Association with the British Council.

Hutchinson, T., \& Waters, A. (1987). English for specific purposes: A learning-centered approach. Cambridge, England: Cambridge University Press. http://dx.doi.org/10.1017/CBO9780511733031

Hyland, K. (1997). Is EAP necessary? A survey of Hong Kong undergraduates. Asian Journal of English Language Teaching, 7, 77-99.

Hyland, K. (2006). English for Academic Purposes: An advanced resource book. London, England: Routledge. http://dx.doi.org/10.1016/j.jeap.2006.07.005

Kavaliauskiene, G., \& Uzpaliene, D. (2003). Ongoing needs analysis as a factor to language learning. Journal of Language and Learning, 1(1), 4-11.

Liang, Y. (2006). Gaoxiao shuangyu jiaoxue xianzhuang ji duice [The current situation of bilingual education in China and possible counter measures]. Higher Educational Research and Evaluation, 5, 46-47.

Littlewood, W., \& Liu, N. F. (1996). Hong Kong students and their English. Hong Kong: Macmillan.

Shaw, P., \& Liu, T. K. (1998). What develops in the development of second-language writing? Applied Linguistics, 19(2), 225-254. http://dx.doi.org/10.1093/applin/19.2.225

Sun, W. (2004). Yingyu zhuanye xueshi lunwen xiezuo xianzhuang fenxi [The problems in thesis writing of undergraduate students majoring in English in China]. Foreign Language World, 3, 59-64.

Swales, J. (1990). Genre analysis: English in academic and research settings. New York, NY: Cambridge University Press.

Swales, J., \& Feak, C. (2004). Academic writing for graduate students: Essential tasks and skills (2nd ed.). Ann Arbor, MI: University of Michigan Press.

West, R. (1994). Needs analysis in language teaching. Language Teaching, 271), 1-19. http://dx.doi.org/10.1017/S0261444800007527

$\mathrm{Xu}, \mathrm{L}$. L. (2005). A genre-based approach to the writing of the introduction section of an ESL / EFL academic paper. Sino-US English Teaching, 2, 22-26.

You, X. (2004). New directions in EFL writing: A report from China. Journal of Second Language Writing, 13, 253-256. http://dx.doi.org/10.1016/j.jslw.2004.09.002 
Zhang, W., \& Luo, L. (2004). Some thoughts on the development and current situation of college English teaching in China. Foreign Language World, 3, 2-7. 


\section{Appendix \\ Summary of Questionnaire Items}

\section{Section I. Your Perceptions on Learning Academic Writing}

On a scale of 1 (least important) to 5 (most important), indicate how important you think academic writing skills are in your current studies and future career.

\begin{tabular}{|l|l|c|l|l|l|c|}
\hline \multicolumn{2}{|l|}{} & $\begin{array}{c}\text { Least } \\
\text { important }\end{array}$ & & & $\begin{array}{c}\text { Most } \\
\text { important }\end{array}$ \\
\hline a) & $\begin{array}{l}\text { How important do you think academic writing skills } \\
\text { are to your current graduate studies? }\end{array}$ & 1 & 2 & 3 & 4 & 5 \\
\hline b) & $\begin{array}{l}\text { How important do you think academic writing is to } \\
\text { your future career in the long run? }\end{array}$ & 1 & 2 & 3 & 4 & 5 \\
\hline c) & $\begin{array}{l}\text { How important it is to have your academic work } \\
\text { published during your graduate study? }\end{array}$ & 1 & 2 & 3 & 4 & 5 \\
\hline
\end{tabular}

Are you interested in academic writing at heart? Please choose from 1-not interested to 5very interested.

$$
\begin{array}{lllll}
1 & 2 & 3 & 4 & 5
\end{array}
$$

Which one(s) of the following text types do you think should be of priority to be taught in an academic writing class? Please check in the box. You can check more than one answer.
$\square$ Writing research papers / reports
$\square$ Writing general argumentative essays
$\square$ Writing research proposal
$\square$ Writing review articles
$\square$ Writing short summaries
$\square$ Writing critiques
$\square$ Writing thesis
$\square$ Writing case studies 
Section II. Your Perceptions on Academic Writing Skills

On a scale of 1 to 5 , indicate how easy or how difficult you think the following skills are.

\begin{tabular}{|c|c|c|c|c|c|c|}
\hline & & $\begin{array}{l}\text { Very } \\
\text { Easy }\end{array}$ & & & & $\begin{array}{c}\text { Very } \\
\text { Difficult }\end{array}$ \\
\hline \multicolumn{7}{|c|}{ General writing skills } \\
\hline a) & Writing introductions & 1 & 2 & 3 & 4 & 5 \\
\hline b) & $\begin{array}{l}\text { Searching for appropriate literature using databases and library } \\
\text { resources }\end{array}$ & 1 & 2 & 3 & 4 & 5 \\
\hline c) & Referring to sources & 1 & 2 & 3 & 4 & 5 \\
\hline d) & $\begin{array}{l}\text { Reviewing and critiquing the previous research and creating a } \\
\text { research space (gap) }\end{array}$ & 1 & 2 & 3 & 4 & 5 \\
\hline e) & Designing the research methods & 1 & 2 & 3 & 4 & 5 \\
\hline f) & Writing up the methods section & 1 & 2 & 3 & 4 & 5 \\
\hline g) & Summarizing and presenting the data & 1 & 2 & 3 & 4 & 5 \\
\hline h) & Commentaries and discussions on the data & 1 & 2 & 3 & 4 & 5 \\
\hline i) & Writing references / bibliography & 1 & 2 & 3 & 4 & 5 \\
\hline j) & Writing conclusions & 1 & 2 & 3 & 4 & 5 \\
\hline k) & Proof-reading written assignments & 1 & 2 & 3 & 4 & 5 \\
\hline \multicolumn{7}{|c|}{ Language problems } \\
\hline a) & $\begin{array}{l}\text { Understanding the specific language features of the academic } \\
\text { genre (such as research paper) }\end{array}$ & 1 & 2 & 3 & 4 & 5 \\
\hline b) & $\begin{array}{l}\text { Using appropriate lexical phrases (such as on the basis of, it } \\
\text { should be noted that) freely to build up the sentences and } \\
\text { paragraphs }\end{array}$ & 1 & 2 & 3 & 4 & 5 \\
\hline c) & Summarizing / paraphrasing & 1 & 2 & 3 & 4 & 5 \\
\hline d) & Writing coherent paragraphs & 1 & 2 & 3 & 4 & 5 \\
\hline e) & Linking sentences smoothly & 1 & 2 & 3 & 4 & 5 \\
\hline f) & Using proper academic language and vocabulary (style) & 1 & 2 & 3 & 4 & 5 \\
\hline g) & $\begin{array}{l}\text { Using the proper grammar such as correct tenses, agreements, } \\
\text { reporting verbs, and prepositions }\end{array}$ & 1 & 2 & 3 & 4 & 5 \\
\hline h) & $\begin{array}{l}\text { Please specify other academic writing skills and mark the } \\
\text { difficulty, if any: }\end{array}$ & 1 & 2 & 3 & 4 & 5 \\
\hline
\end{tabular}




\section{Section III. The Previous and Future Academic Writing Courses}

\section{The Previous Academic Writing Course}

Is there any academic writing (or thesis / research paper writing) course offered at your university for graduate students?

$\square$ Yes $\square$ No

Have you taken any academic writing (or thesis writing) course during your undergraduate studies?

$\square$ Yes, the name of the course is

$\square$ No (Please skip Questions 7-9 and answer Questions 10 and 11)

Are you satisfied with the previous academic writing course generally?

$\square$ It was perfect $\square$ Generally satisfied $\square$ Just so so $\square$ Not satisfied at all

Have you learned the things that you need to learn most in your previous academic writing course?

$\square$ Yes, I have learned a lot and they are still useful now.

$\square$ I have learned something useful.

$\square$ The course was generally OK, but it did not teach me the things that I want to learn most.

$\square$ The course was organized very poorly and I learned nothing useful.

Which academic writing skills were taught in your previous academic writing course?

\begin{tabular}{|l|l|c|c|c|c|c|}
\hline \multicolumn{2}{|l|}{} & $\begin{array}{c}\text { Very } \\
\text { Easy }\end{array}$ & & \multicolumn{2}{|c|}{$\begin{array}{c}\text { Very } \\
\text { Difficult }\end{array}$} \\
\hline \multicolumn{2}{|l|}{ General writing skills } & 1 & 2 & 3 & 4 & 5 \\
\hline a) & Writing introductions & 1 & 2 & 3 & 4 & 5 \\
\hline b) & $\begin{array}{l}\text { Searching for appropriate literature using databases and library } \\
\text { resources }\end{array}$ & 1 & 2 & 3 & 4 & 5 \\
\hline c) & Referring to sources & 1 & 2 & 3 & 4 & 5 \\
\hline d) & $\begin{array}{l}\text { Reviewing and critiquing the previous research and creating a } \\
\text { research space (gap) }\end{array}$ & 1 & 2 & 3 & 4 & 5 \\
\hline e) & Designing the research methods & 1 & 2 & 3 & 4 & 5 \\
\hline f) & Writing up the methods section & 1 & 2 & 3 & 4 & 5 \\
\hline g) & Summarizing and presenting the data & 1 & 2 & 3 & 4 & 5 \\
\hline h) & Commentaries and discussions on the data & 1 & 2 & 3 & 4 & 5 \\
\hline i) & Writing references / bibliography & 1 & 2 & 3 & 4 & 5 \\
\hline j) & Writing conclusions & 1 & 2 & 3 & 4 & 5 \\
\hline k) & Proof-reading written assignments & &
\end{tabular}




\begin{tabular}{|l|l|l|l|l|l|c|}
\hline \multicolumn{2}{|l|}{ Language problems } \\
\hline a) & $\begin{array}{l}\text { Understanding the specific language features of the academic } \\
\text { genre (such as research paper) }\end{array}$ & 1 & 2 & 3 & 4 & 5 \\
\hline b) & $\begin{array}{l}\text { Using appropriate lexical phrases (such as on the basis of, it } \\
\text { should be noted that) freely to build up the sentences and } \\
\text { paragraphs }\end{array}$ & 1 & 2 & 3 & 4 & 5 \\
\hline c) & Summarizing / paraphrasing & 1 & 2 & 3 & 4 & 5 \\
\hline d) & Writing coherent paragraphs & 1 & 2 & 3 & 4 & 5 \\
\hline e) & Linking sentences smoothly & 1 & 2 & 3 & 4 & 5 \\
\hline f) & Using proper academic language and vocabulary (style) & 1 & 2 & 3 & 4 & 5 \\
\hline g) & $\begin{array}{l}\text { Using the proper grammar such as correct tenses, agreements, } \\
\text { reporting verbs, and prepositions }\end{array}$ & 1 & 2 & 3 & 4 & 5 \\
\hline h) & $\begin{array}{l}\text { Please specify other academic writing skills and mark the } \\
\text { difficulty, if any: }\end{array}$ & 1 & 2 & 3 & 4 & 5 \\
\hline
\end{tabular}

What types of teaching activities took place in your previous academic writing class? Please also indicate your preference of these activities if they were to be provided in a new course by checking in the box (from 1, least preferable, to 5, most preferable). If you have not taken an academic writing course before, please indicate your preference only.

\begin{tabular}{|l|c|c|c|c|c|}
\hline & $\begin{array}{c}\text { Least } \\
\text { preferable }\end{array}$ & & & $\begin{array}{c}\text { Most } \\
\text { preferable }\end{array}$ \\
\hline The key textbook used in class & 1 & 2 & 3 & 4 & 5 \\
\hline Other supplementary handouts & 1 & 2 & 3 & 4 & 5 \\
\hline Supplementary authentic research papers as models & 1 & 2 & 3 & 4 & 5 \\
\hline Supplementary exercises _and check for preference) & 1 & 2 & 3 & 4 & 5 \\
\hline Others (please specify _a & & 2 & 3 & 4 & 5 \\
\hline
\end{tabular}

\begin{tabular}{|l|c|c|c|c|c|c|}
\hline & $\begin{array}{c}\text { Least } \\
\text { frequent }\end{array}$ & & & $\begin{array}{c}\text { Most } \\
\text { frequent }\end{array}$ & Preference \\
\hline Teacher-centered lectures & 1 & 2 & 3 & 4 & 5 & $\square$ \\
\hline Student oral presentations & 1 & 2 & 3 & 4 & 5 & $\square$ \\
\hline Group discussions on tasks & 1 & 2 & 3 & 4 & 5 & $\square$ \\
\hline Academic grammar drills & 1 & 2 & 3 & 4 & 5 & $\square$ \\
\hline Academic vocabulary drills & 1 & 2 & 3 & 4 & 5 & $\square$ \\
\hline Academic writing exercises & 1 & 2 & 3 & 4 & 5 & $\square$ \\
\hline Academic reading exercises (reading textbooks) & 1 & 2 & 3 & 4 & 5 & $\square$ \\
\hline Reading and analyzing authentic research papers & 1 & 2 & 3 & 4 & 5 & $\square$ \\
\hline $\begin{array}{l}\text { Others (please specify _and check for } \\
\text { preference) }\end{array}$ & 1 & 2 & 3 & 4 & 5 & $\square$ \\
\hline
\end{tabular}


How did you like the teaching materials in your previous writing course? For those who have not taken a course before, you can still check for your preference if they were provided in a new course.

$\square$ reading textbooks

$\square$ writing one complete essay / research paper / proposal as term paper

$\square$ writing parts of an essay / research paper

$\square$ reading other materials, such as research papers

$\square$ other (please specify):

What kind(s) of after-class assignments did you have in your previous academic writing class? You can check for more than one answer. If you have not taken an academic writing course, please skip this question.

$\square$ reading textbooks

$\square$ writing one complete essay / research paper / proposal as term paper

$\square$ writing parts of an essay / research paper

$\square$ reading other materials, such as research papers

$\square$ other (please specify):

\section{The Future Academic Writing Course}

Do you think it is necessary for you to take an English academic writing course (specifically research paper writing) in your graduate studies? $\square$ Yes $\square$ No

What do you think the focus of the academic writing course should be more on?

$\square$ General writing skills $\square$ Language problems

If a new academic writing course is offered, please write down the most important five skills that you want to learn in the new course:

1. 2. 3. 4. 5.

Personal Information

Age Gender

The name of the institution where you did your undergraduate studies

Have you ever been to English speaking countries? $\square$ Yes $\square$ No If yes, for how long? 